VOLUME 15 - NUMBER 2 - MAY-AUGUST 2015

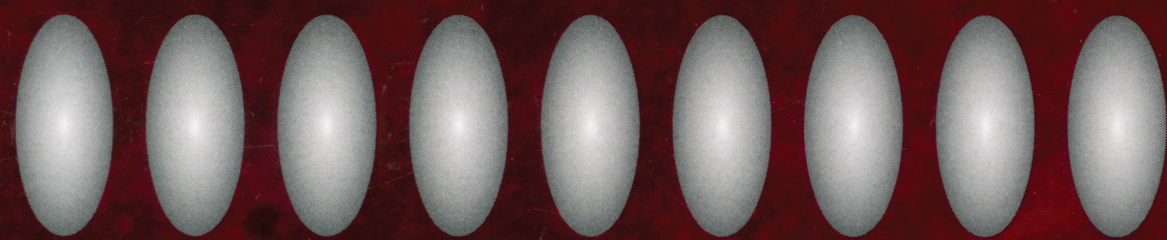

\title{
Journal of East
} Asian Studies

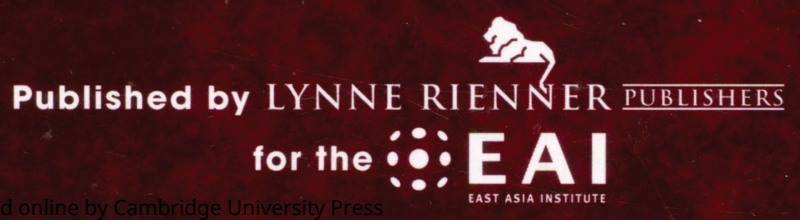


Editor

Stephan Haggard, University of California, San Diego

\section{Associate Editors}

Yun-han Chu, Academia Sinica

Byung-Kook Kim, Korea University

Xiaobo Lu, Columbia University

Andrew MacIntyre, Australian National University

Yoshihide Soeya, Keio University

\section{Managing Editor}

Young-Hwan Shin, East Asia Institute

\section{Book Review Editor}

Yves Tiberghien, University of British Columbia

\section{Editorial Board}

Muthiah Alagappa, Institute of Strategic and International Studies, Malaysia

Gordon de Brouwer, Australian National University

Steve Chan, University of Colorado

Beng Huat Chua, National University of Singapore

Larry Diamond, Hoover Institution

Emmanuel de Dios, University of the Philippines

Jorge I. Domínguez, Harvard University

Peter Evans, University of California, Berkeley

Sung-Joo Han, International Policy Studies Institute of Korea

Szu-yin Ho, National Chengchi University

Paul D. Hutchcroft, Australian National University

Takashi Inoguchi, University of Niigata Prefecture

Qingguo Jia, Peking University

K. S. Jomo, UN Department of Economic and Social Affairs

Ryosei Kokubun, Keio University

Shin-wha Lee, Korea University

Sook-Jong Lee, Sungkyunkwan University

Hyun-Chin Lim, Seoul National University

Linda Lim, University of Michigan

Jongryn Mo, Yonsei University

Andrew J. Nathan, Columbia University

Gregory W. Noble, University of Tokyo

John S. Odell, University of Southern California

T. J. Pempel, University of California, Berkeley

Denny Roy, East-West Center

Gilbert Rozman, Princeton University

Miranda A. Schreurs, Freie Universität Berlin

Dingli Shen, Fudan University

Jin-Young Suh, Korea University

Akihiko Tanaka, University of Tokyo

James T. H. Tang, University of Hong Kong

Ezra F. Vogel, Harvard University

Yizhou Wang, Chinese Academy of Social Sciences

Meredith Jung-En Woo, University of Virginia

Yu-shan Wu, Academia Sinica
The Journal of East Asian Studies was supported by the National Research Foundation of Korea Grant funded by the Korean Government (MOE).

The Journal of East Asian Studies (print ISSN 1598-2408; online ISSN 2234-6643) is published three times yearly (in Jan.-Apr., May-Aug., and Sept.-Dec.) by Lynne Rienner Publishers, Inc., 1800 30th St., Suite 314, Boulder, CO 80301-1026. POSTMASTER: Send address changes to Journal of East Asian Studies, Lynne Rienner Publishers, 1800 30th St., Suite 314, Boulder, CO 80301-1026 or journals @rienner.com.

\section{Annual Subscriptions}

Subscription orders and inquiries should be sent to Lynne Rienner Publishers at the address above or by going to www.rienner.com/JEAS.

For institutions, the basic annual subscription rate is $\$ 138$. For individuals, the rate is $\$ 63$, and the student rate is $\$ 33$; payment must accompany orders. For delivery outside the United States, please add $\$ 18$ for international postage. All subscriptions include electronic access. For questions about electronic access to JEAS, contact journals@rienner.com.

(c) 2015 by the East Asia Institute. All rights reserved. No part of this publication may be reproduced or transmitted in any form or by any means (including photocopying) without the permission of the publisher.

Authorization to photocopy items for internal or personal use is granted by Lynne Rienner Publishers, Inc., provided that the base fee of $\$ 3$ per article per copy is paid directly to the Copyright Clearance Center, 27 Congress Street, Salem, MA 01970, USA. For those organizations that have been granted a photocopy license by $\mathrm{CCC}$, a separate system of payment has been arranged.

JEAS is indexed by OCLC PAIS and Social Sciences Citation Index (SSCI), abstracted by Academic Search Premier, International Bibliography of the Social Sciences, International Political Science Abstracts, Journal Citation Reports/Social Sciences Edition, Scopus, and Social Scisearch and referenced by EBSCO Host and Gale Group.

Printed and bound in the United States of America ISSN 1598-2408
The paper used in this publication meets the requireThen of the American National Standard for Permanence of Paper for Printed Library Materials Z39.48-1992.

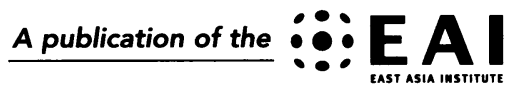




\section{Journal of East Asian Studies}

VOLUME 15

NUMBER 2

MAY-AUg. 2015

\section{Articles}

The 2013 Malaysian Elections: Ethnic Politics or Urban Wave?

Jason Wei Jian Ng, Gary John Rangel, Santha

Vaithilingam, and Subramaniam S. Pillay

Interpreting Ethnicity and Urbanization in Malaysia's 2013

General Election Thomas B. Pepinsky

Rejoinder: The Authors Respond to "Interpreting Ethnicity and Urbanization in Malaysia's 2013 General Election"

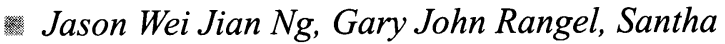
Vaithilingam, and Subramaniam S. Pillay

National Interest or Transnational Alliances? Japanese Policy on the Comfort Women Issue 촘 Yangmo Ku

The Impact of the 2008 Labor Contract Law on Labor Disputes in China Thomas F. Remington and Xiao Wen Cui

\section{Book Reviews}

Linda Benson. China Since 1949, 2nd ed. Reviewed by Bryan Winter

Jacques Bertrand. Political Change in Southeast Asia. Reviewed by Kai Ostwald

Paul Evans. Engaging China: Myth, Aspiration, and Strategy in Canadian Policy from Trudeau to Harper. Reviewed by Kim Richard Nossal 
Leta Hong Fincher. Leftover Women: The Resurgence of Gender Inequality in China. Reviewed by Hang Lin

Nicholas R. Lardy. Markets over Mao: The Rise of

Private Business in China. Reviewed by Linting Zhang

Yuhki Tajima. The Institutional Origins of

Communal Violence: Indonesia's Transition from Authoritarian Rule. Reviewed by Diego Fossati

The Contributors 